\title{
The Dental Traits of Indonesian Javanese
}

\author{
Myrtati Dyah Artaria
}

\begin{abstract}
Department of Anthropology, FISIP, Universitas Airlangga, Jl. Airlangga 4-6, Surabaya, East Java, Indonesia 60286 Dental Traits of Indonesian Javanese
\end{abstract}

ABSTRACT This study describes the dental crown morphology of 91 Javanese of known sex and age, in Surabaya, East Java. The purpose was to explore the dental morphology in the area of East Java, especially in Surabaya. I scored a battery of three dozen dental traits on the permanent dentition (sexes pooled). Comparisons of

The dental morphology of Southeast Asia is poorly known. Studies in dental anthropology have never been conducted on Indonesians even though the area has a rich variety of peoples and cultures. Data on the variety of populations in this area may be useful regarding human evolution (Hillson, 2002), migration patterns (Scott and Turner, 2000), and for evaluating forensic cases (Brown, 1992). Previous studies have assessed menarcheal age (Artaria and Henneberg, 2000), mesiodistal diameters of the primary dentition (Kuswandari and Nishino, 2004), and adolescents' growth and development (Artaria, 2009), but little has been found on the characteristics of the dentition in Javanese people, so it is useful to initiate studies of this kind.

Previous study on the Javanese dentition (Artaria, 2007) found that shovel shape, winging, tuberculum dentale, interruption groove, canine distal accessory ridge, premolar accessory ridges, premolar multiple lingual cusps, cusp 5, cusp 6, Y5 pattern, cusp 7, protostylid, deflecting wrinkle, anterior fovea, and Carabelli's cusp occurred in the sample. However, that preliminary sample size was small, and no scoring was done for each variable.

The literature suggest that dental variation is heritable, the traits appear to be controlled by multiple genes, and they are little influenced by environmental factors (Rodríguez-Flórez et al., 2006), so phenotypic differences among samples can be interpreted as differences in genotypic composition (Varela and Cocilovo, 2000). Phenotypic similarity is suggested to approximate genetic similarity.

Research on the primary dentition of Javanese children (Kuswandari and Nishino, 2004) found that the mesiodistal tooth diameters fell between those of Australian Aboriginals and Hong Kong Chinese. This makes sense because Jacob (1967) and others note that the islands of Indonesia historically were occupied by ancient Homo sapiens similar to those of the Australians. the trait frequencies show that this Javanese sample does not exhibit a classic combination either of the Sinodont or Sundadont dental patterns. Instead, it represents some features of each, and this probably is due to the millennia of human migrations through this region. Dental Anthropology 2010(23):74-78.

The teeth of the Javanese may reflect the admixture of two ancestral lines, namely Australomelanesid and Mongoloid.

The goal of the present research was to describe the frequencies of some common dental traits as they were represented in a contemporary sample of Javanese.

\section{MATERIAL AND METHODS}

The sample was 91 individuals from the Surabaya, East Java (Indonesia). The dental traits examined were shovel shape, double shovel, winging, tuberculum dentale, interruption groove, canine distal accessory ridges, Carabelli's cusp, odontomes, premolar accessory ridge, parastyle, multiple lingual cusps, Dryopithecus pattern, Cusp 5, Cusp 6, Cusp 7, deflecting wrinkle, anterior fovea, protostylid, and uncommon shape/place of lateral incisors. Dental traits were scored using the descriptions in Scott and Turner (2000), and the dental plaques provided by ASU. Percentages were counted using simple descriptive statistic analysis.

\section{RESULTS AND DISCUSSION}

Scott and Turner (2000) have divided the world's populations into five groups based on their dentitions. The dental traits of Sahul-Pacific group - the same area occupied by the Australomelanesid according to Jacob (1967)-exhibit dental characteristics such as frequent expression of cusp 5, Carabelli's cusp, and cusp 6. In contrast, there are rare expressions of winging, shoveling, double shoveling, interruption grooves, and cusp 7. Further, they have intermediate position for several

Correspondence: Myrtati Dyah Artaria, Department of Anthropology, FISIP, Universitas Airlangga, Jl. Airlangga 4-6, Surabaya 60286, Indonesia.

Grant sponsorship: FISIP UNAIR Grant

E-mail: myrtati@gmail.com 
traits such as odontomes, 4 cusped LM1 and LM2, LM2 Y pattern, and deflecting wrinkle.

The Sino-Americas group, according to Scott and Turner (2000) has characteristics of dentition such as high frequency of winging, double shoveling, interruption grooves, odontomes, cusp 6, and deflecting wrinkle. The Sunda Pacific groups have no high frequency dental traits that set them apart; however, they have high frequencies of Carabelli's cusp and cusp 6, and low frequencies of cusp 7 and 4-cusped LM1.

Shovel shape had been widely studied by several authors (e.g., Campusano et al., 1972; Dahlberg, 1951; DeVoto et al., 1968; Bollini et al., 2006; Nelson, 1938; Rothhammer et al., 1968). Most of these studies concluded that high frequency of strong shovel shaped incisors was found in Mongoloid populations, especially those descendants of Mongoloid people from the Asian continent. A study by Bollini et al. (2009) reported a high frequency of shovel shape (80\%) but absence of Carabelli's complex in the Pre-Conquest sample "Calchaquí" from Argentina.

In the present sample, shovel shape was common, although the expressions were mostly grades 2 and 3 (Table 1) using the ASU shovel shape dental plaque. This is expected given the Asian ancestry of the group, especially the Sundadont. The most frequent degree of expression for upper first incisor and lateral incisors was 2. It was also noteworthy that the frequency of the sample that did not have shoveled-shape upper incisors was comparatively high $-8 \%$ to $9 \%$ (Table 1 ). These frequencies for shoveling suggest similarities to the Sunda Pacific group.

Some subjects have slight double shovel (Table 1). The frequency of double shovel in recent Southeast Asia predicted by Scott and Turner (2000) is 5\% to 18\%. However, this higher frequency in these Javanese may reflect admixture of the Surabayan people in the coastal

TABLE 1. Percentages of shovel and double shovel shape ${ }^{\dagger}$

\begin{tabular}{|c|c|c|c|c|c|}
\hline \multirow[b]{2}{*}{ Grade } & \multirow{2}{*}{$\begin{array}{c}\text { Shovel } \\
\text { UI1 }\end{array}$} & \multirow{2}{*}{$\begin{array}{c}\text { Shovel } \\
\text { UI2 }\end{array}$} & \multirow{2}{*}{$\begin{array}{l}\text { Shovel } \\
\text { lower } \\
\text { I and C } \\
\end{array}$} & \multicolumn{2}{|c|}{ Double shovel } \\
\hline & & & & UI1 & UI2 \\
\hline 0 & 8.8 & 7.7 & 62.3 & 26.2 & 53.3 \\
\hline 1 & 8.8 & 24.2 & 27.9 & 57.4 & 38.3 \\
\hline 2 & 40.7 & 30.8 & 8.2 & 14.8 & 7.4 \\
\hline 3 & 24.2 & 17.6 & 1.6 & 1.6 & 0.0 \\
\hline 4 & 9.9 & 13.2 & 0.0 & 0.0 & 0.0 \\
\hline 5 & 7.7 & 3.3 & 0.0 & 0.0 & 0.0 \\
\hline 6 & 0.0 & 0.0 & 0.0 & 0.0 & 0.0 \\
\hline 7 & 0.0 & 2.2 & 0.0 & 0.0 & 0.0 \\
\hline Missing & 0.0 & 1.0 & 0.0 & 0.0 & 1.0 \\
\hline Total & 100.0 & 100.0 & 100.0 & 100.0 & 100.0 \\
\hline
\end{tabular}

tUI1: upper central incisor, UI2: upper lateral incisor, I: incisor, C: canine
TABLE 2. Percentage of tuberculum dentale (TD), interruption groove (IG), maxillary incisor winging, and uncommon shape/ place of lateral incisors (LI)

\begin{tabular}{crrcc}
\hline Grade & TD & IG & Winging & LI Shape \\
\hline 0 & 47.3 & 86.7 & 84.6 & 0.0 \\
1 & 18.7 & 12.3 & 7.7 & 0.0 \\
2 & 24.2 & 0.0 & 5.5 & 0.0 \\
3 & 3.3 & 0.0 & 2.2 & 0.0 \\
Absent & 0.0 & 0.0 & 0.0 & 98.3 \\
Present & 0.0 & 0.0 & 0.0 & 1.7 \\
Missing & 0.0 & 1.0 & 0.0 & 0.0 \\
Total & 100.0 & 100.0 & 100.0 & 100.0 \\
\hline
\end{tabular}

area of northeast Java with the Sinodont-people from Asia who migrated to the Indonesian areas during the first to second centuries. Double shovel was found in the upper central incisors in $73 \%$ of the sample, but only in a weak expression, scores 1 to 3 , and $47 \%$ of the sample had double shovel of their lateral incisors. Double shoveling frequency is similar to that of the Sunda Pacific group.

High frequencies of winging are usually found in Sinodont dentitions, especially groups in northeast Siberia and North America. The people of Java are labeled Sundadont, and some data suggest that Sundadont groups may also have high frequencies of winging. The Sunda Pacific group is suggested to exhibit winging on the order of $15 \%$ to $28 \%$ (Scott and Turner, 2000). Incisor winging occurred in $15 \%$ of the present sample (Table 2), so it is comparable to the Sunda Pacific group as described by Scott and Turner.

Expression of tuberculum dentale was weak to moderate, and most individuals-47\%-lacked tuberculum dentale on their central incisors (Table 2). Only 3\% exhibited a more pronounced-score 3 -grade of tuberculum dentale. This is neither characteristic of Sino Americas nor Sahul Pacific, but more like that of Sunda Pacific groups.

According to Scott and Turner (2000), the SundaPacific people-including Southeast Asians-have frequencies of $25 \%$ to $35 \%$ with interruption grooves on the second incisors. However, interruption grooves on the upper second incisors occurred in only $12 \%$ of the current sample (Table 2). This low frequency of interruption grooves is more similar to Sahul Pacific groups.

Upper lateral incisors can undergo rotation, crowding, or reduced size (Table 2), and the uncommon shape or placement of lateral incisors occurred in a small number of the sample (2\%). Instead of having uncommon shape/ size of lateral incisors - as is more common in Caucasian samples, Mongoloids seem to have more cases of winging of central incisors (C. G. Turner, pers. comm.).

No Bushmen canine was found in the sample. Canine distal accessory ridge occurred in $69 \%$ of the sample (Table 3). The occurrence of distal accessory ridges on 
TABLE 3. Percentages of distal accessory ridge (DAR) and the Bushmen canine ${ }^{\dagger}$

\begin{tabular}{cccc}
\hline Score & DAR UC & DAR LC & $\begin{array}{c}\text { Bushmen } \\
\text { UC }\end{array}$ \\
\hline 0 & 31.1 & 88.5 & 100.0 \\
1 & 49.2 & 11.5 & 0.0 \\
2 & 19.7 & 0.0 & 0.0 \\
Missing & 0.0 & 0.0 & 0.0 \\
Total & 100.0 & 100.0 & 100.0 \\
\hline
\end{tabular}

${ }^{\dagger} \mathrm{U}=$ upper, $\mathrm{L}=$ lower, $\mathrm{C}=$ canine

the lower canine was less common (12\% of the sample). Research is needed to find out whether there is sexual dimorphism in this particular trait.

There was an indication of sexual dimorphismmales having larger cusps - for Carabelli's trait (Khraisat et al., 2007). According to Mavrodisz et al. (2007), there is a genetic influence on the Carabelli's trait. There also is a positive association between Carabelli's cusp and tooth crown size (Garn et al., 1966; Harris, 2007). Carabelli's trait complex was expressed in more than $70 \%$ of the cases (Table 4), with the degree of expression ranging from 0 to 7 . The high percentage of Carabelli's cusp is the characteristic of both Sunda Pacific and Sahul Pacific. However, according to Scott and Turner (2000), the percentage may reach $25 \%$, but not as high as $70 \%$. This outstanding occurrence of Carabelli's cusp may be related to some other factors, such as the size of the tooth crown (Harris, 2007) or sampling fluctuation. Further research in this matter may be conducted in the near future.

The parastyle occurred on $2 \%$ (M3) to $6 \%$ (M2) of the molars, while no parastyle nor cusp 5 was found on M1 (Table 4). The absence of cusp 5 certainly is not a characteristic of Sahul Pacific groups; it is more characteristic of Sino Americans according to Scott and Turner (2000).

The groove pattern was mostly of the $\mathrm{X}$ pattern (Table
5). The Dryopithecus pattern (Y pattern LM2) was found in $7 \%$ of the sample. The frequency of the $\mathrm{Y}$ pattern of Australians (Sahul Pacific group) is approximately $21 \%$. The percentage of Y pattern on LM2 in China Mongolia and North and South America (Sino Americas group) is around $8-9 \%$, and in the Sunda Pacific is around 19\% (Scott and Turner, 2000), so the percentage of the Y pattern in this sample was closer to the Sino American condition.

Cusp 6 was found in $6 \%$ of the sample, and no cusp 7 was found (Table 5). The closest percentage of cusp 6 occurrence was the New Guinea people (Sahul Pacific) that has around $18 \%$ of people with the dental trait. The south Siberian (Sino American group) has $20 \%$, and the Southeast Asians (Sunda Pacific group) 32\% (Scott and Turner, 2000). Cusp 7 is a common characteristic in SubSaharan peoples, while low frequencies $(0-10 \%)$ generally occur in the Sino Americas, Sahul Pacific, and Sunda Pacific groups (Scott and Turner, 2000), so this accessory cusp is, not surprisingly, absent in this Javanese sample.

Most of the sample (above 90\%) had no deflecting wrinkle or anterior fovea (Table 5). Deflecting wrinkle was found in 3\%, and anterior fovea was in $7 \%$ of the sample. The closest percentage of deflecting wrinkle was found in the New Guinean people-around 5\% of the people. The recent Southeast Asian (Sunda Pacific group) has 15\%, and other Sino Americas around 30\% and above (Scott and Turner, 2000).

The protostylid occurred predominately on M1, with a frequency above $50 \%$ (Table 5). Similar to the Carabelli cusp, the protostylid also is positively associated with crown size (Scott and Turner, 2000). Further they stated that the protostylid was frequently expressed on LM1 which was true for this sample, but when it appeared on LM2 the size often was bigger.

Accessory ridge was found in $10 \%$ to $29 \%$ of the upper premolars in the sample (Table 6), while the percentage of sample having accessory ridges on the lower premolars was even less, namely 1-2\% (Table 7) as expected. There were no odontomes (Table 6 and 7), although Scott and Turner (2000) estimated that 1 to $4 \%$ of recent Southeast

TABLE 4. Trait percentages on the upper molars ${ }^{\dagger}$

\begin{tabular}{ccccccr}
\hline Score & UM1C & UM2C & UM1C5 & UM1PA & UM2PA & UM3PA \\
\hline 0 & 20.9 & 71.4 & 100.0 & 100.0 & 93.3 & 17.6 \\
1 & 40.7 & 15.4 & 0.0 & 0.0 & 5.6 & 2.2 \\
2 & 20.9 & 12.1 & 0.0 & 0.0 & 0.0 & 0.0 \\
3 & 9.9 & 0.0 & 0.0 & 0.0 & 0.0 & 0.0 \\
4 & 2.2 & 0.0 & 0.0 & 0.0 & 0.0 & 0.0 \\
5 & 2.2 & 0.0 & 0.0 & 0.0 & 0.0 & 0.0 \\
6 & 0.0 & 0.0 & 0.0 & 0.0 & 0.0 & 0.0 \\
7 & 3.3 & 0.0 & 0.0 & 0.0 & 1.1 & 80.2 \\
Missing & 0.0 & 1.1 & 0.0 & 0.0 & 100.0 & 100.0 \\
Total & 100.0 & 100.0 & 100.0 & 100.0 & & 0 \\
\hline
\end{tabular}

${ }^{\dagger} \mathrm{U}=$ upper, $\mathrm{M}=$ molar, $\mathrm{C}=$ Carabelli's cusp, $\mathrm{C} 5=\operatorname{cusp} 5, \mathrm{PA}=$ parastyle 
TABLE 5. Percentage of traits in lower molars ${ }^{\dagger}$

\begin{tabular}{crrrrrrrr}
\hline Score & LM2GP & LM1C6 & LM1C7 & LM1DW & LM1AF & LM1PO & LM2PO & LM3PO \\
\hline 0 & 24.6 & 94.3 & 100.0 & 96.2 & 92.6 & 47.3 & 65.6 & 13.2 \\
1 & 6.6 & 5.7 & 0.0 & 3.8 & 7.4 & 52.7 & 34.4 & 4.4 \\
2 & 65.6 & 0.0 & 0.0 & 0.0 & 0.0 & 0.0 & 0.0 & 0.0 \\
3 & 3.3 & 0.0 & 0.0 & 0.0 & 0.0 & 0.0 & 0.0 & 0.0 \\
Missing & 0.0 & 0.0 & 0.0 & 0.0 & 0.0 & 0.0 & 0.0 & 82.4 \\
Total & 100.0 & 100.0 & 100.0 & 100.0 & 100.0 & 100.0 & 100.0 & 100.0 \\
\hline
\end{tabular}

${ }^{\dagger} \mathrm{L}=$ lower, $\mathrm{M}=$ molar, $\mathrm{GP}=$ groove pattern, score 0: unclear groove/missing tooth, score 1: Dryopithecus pattern, score 2: $\mathrm{X}$ pattern, score 3: + pattern; $\mathrm{C} 6=\operatorname{cusp} 6, \mathrm{C} 7=\operatorname{cusp} 7, \mathrm{DW}=$ deflecting wrinkle, $\mathrm{AF}=$ anterior fovea, $\mathrm{PO}=$ protostylid

Asian people have odontomes. Multiple lingual cusps were found mostly on the lower second premolar. The cusps were also more complicated on the second lower premolars (Table 7).

\section{CONCLUSION}

Based on the finding in this Javanese sample, the trait frequencies were more like Sunda Pacific. The Sundadont people who have higher frequency of derived traits are thought to have evolved on Sundaland during Upper Pleistocene. They exhibit a "more conservative pattern, typified by trait retention rather than elaboration" (Scott and Turner, 2000). The traits with frequencies similar to the Sunda Pacific group were shoveling, double shovel, winging, and tuberculum dentale.

However, other percentages mirror those of the Sino Americas, and still others those of Sahul Pacific. Trait frequencies similar to Sino Americas were cusp 5 and the Y pattern. Percentages similar to Sahul Pacific were interruption grooves, cusp 6, and deflecting wrinkle. Consequently, this sample of Javanese is not monolithic as regards either the Sinodont or Sundadont dental patterns. Instead, they exhibit some features of each, probably because of the millennia of human migrations through this region.

\section{LITERATURE CITED}

Artaria MD, Henneberg M. 2000. Why did they lie: socioeconomic bias in reporting menarcheal age. Ann Hum Biol 27:561-569.

TABLE 6. The percentage of traits in upper premolars ${ }^{\dagger}$

\begin{tabular}{crrrr}
\hline Score & UP1AR & UP2AR & UP1OD & UP2OD \\
\hline 0 & 90.0 & 71.4 & 100.0 & 100.0 \\
1 & 10.0 & 28.6 & 0.0 & 0.0 \\
Missing & 0.0 & 0.0 & 0.0 & 0.0 \\
Total & 100.0 & 100.0 & 100.0 & 100.0 \\
\hline
\end{tabular}

${ }^{\mathrm{t}} \mathrm{U}=$ upper, $\mathrm{P}=$ premolar, $\mathrm{AR}=$ accessory ridge, $\mathrm{OD}=$ odontome
Artaria MD. 2007. Short communication: Dental trait variation and age determination based on dental wear: A preliminary study of Javanese. Dental Anthropology 20:41-43.

Artaria MD. 2009. Growth of adolescents: cross sectional, mixed longitudinal and longitudinal studies. Lambert Academic Publisher.

Bollini GA, Rodríguez-Flórez CD, Colantonio SE. 2009. Dental Non-Metric Traits in a Pre-Conquest Sample "Calchaquí" From Argentina, South America. Int J Morphol 27:1063-1067.

Bollini GA, Rodríguez-Flórez CD, Colantonio SE and Méndez MG. 2006. Morfología dental de una serie prehistórica de araucanos provenientes de la Patagonia argentina y su relación biológica con otras poblaciones prehistóricas argentinas y del mundo. Int J Morphol 24:705-712.

Brown KA. 1992. Comparative bite marks: differential diagnosis. In: Clark DH. Practical forensic odontology. London: Butterworth-Heinemann Ltd.

Campusano C, Figueroa H, Lazo B, Pinto-Cisternas J and Salinas C. 1972. Some dental traits of Diaguita indian skulls. Am J Phys Anthropol 36:139-142.

Dahlberg AA. The dentition of the American Indian. In: Laughlin WS, editor. The physical anthropology of the American Indian. New York: Viking Fund Inc., 1951, p 138-176.

DeVoto FCH, Arias NH, Ringuelet S and Palma NH. 1968. Shovel-shaped incisors in a Northwertern Argentine population. J Dent Res 47:820-823.

Garn SM, Lewis AB, Kerewsky RS, Dahlberg AA. 1966. Genetic independence of Carabelli's trait from tooth size or crown morphology. Arch Oral Biol 11:745-747.

Harris EF. 2007. Carabelli's trait and tooth size of human maxillary first molars. Am J Phys Anthropol 132:238246.

Hillson S. 2002. Dental anthropology. Cambridge: Cambridge University Press.

Jacob T. 1967. Some Problems Pertaining to the Racial History of the Indonesia Region. Unpublished Thesis. Utrecht. 
TABLE 7. Trait percentage on the lower premolars ${ }^{\dagger}$

\begin{tabular}{crrrrrr}
\hline Score & LP1AR & LP2AR & LP1OD & LP2OD & LP1MLC & LP2MLC \\
\hline 0 & 98.4 & 98.3 & 100.0 & 100.0 & 94.8 & 36.2 \\
1 & 1.6 & 1.7 & 0.0 & 0.0 & 5.2 & 37.9 \\
2 & 0.0 & 0.0 & 0.0 & 0.0 & 0.0 & 22.4 \\
3 & 0.0 & 0.0 & 0.0 & 0.0 & 0.0 & 3.4 \\
Missing & 0.0 & 0.0 & 0.0 & 0.0 & 0.0 & 0.0 \\
Total & 100.0 & 100.0 & 100.0 & 100.0 & 100.0 & 100.0 \\
\hline
\end{tabular}

${ }^{\dagger} \mathrm{L}=$ lower, $\mathrm{P}=$ premolar, $\mathrm{AR}=$ accessory ridge, $\mathrm{OD}=$ odontome, $\mathrm{MLC}=$ multiple lingual cusps

Khraisat A, Taha ST, Jung RE, Hattar S, Smadi L, Al-Omari IK, Jarbawi M. 2007. Prevalence, association, and sexual dimorphism of Carabelli's molar and shovel incisor traits amongst Jordanian population. Odontostomatol Trop 30:17-21.

Kuswandari S, and Nishino M. 2004. The mesiodistal crown diameters of primary dentition in Indonesian Javanese children. Arch Oral Biol 9:217-222.

Maples WR, Browning M. 1994. Death in 10,000 fragments. In: Maples WR and Browning M, editors. Dead men do tell tales. New York: Doubleday.

Mavrodisz K, Rózsa N , Budai M , Soós A., Pap I and Tarján I. 2007. Prevalence of accessory tooth cusps in a contemporary and ancestral hungarian population. Eur J Orthod 29:166-169.

Nelson CT. 1938. The teeth of the Indians Pecos Pueblo. Am J Phys Anthropol 23:261-93.
Rodríguez-Flórez CD, Fonseca GM, Villalba MT. 2006. Brief communication: Occurrence of an eighth cusp on primary second mandibular molars of a contemporary Argentinean child. Dental Anthropology 19:73-75.

Rothhammer F, Lasserre R, Blanco R, Covarrubias E, Dixon M. 1968. Microevolution in human Chilean populations. IV. Shovel shape, mesial-palatal version and other dental traits in Pewenche Indians. Z Morphol Anthropol 60:162-169.

Scott GR, Turner CG II. 2000. The anthropology of modern human teeth. Cambridge: Cambridge University Press.

Varela HH, Cocilovo JA. 2000. Structure of the prehistoric population of San Pedro de Atacama. Curr Anthropol 41:125-131. 